\title{
2030 agenda and its considerations in the framework of artisanal fishing cooperatives in Mexico
}

\author{
Magadán-Revelo L. D. ${ }^{1 *}$; Escalona-Maurice M. J. ${ }^{1}$; Aguilar-Ibarra A. ${ }^{2}$; Hernández-Juárez M. ${ }^{1}$ \\ ${ }^{1}$ Colegio de Postgraduados Campus Montecillo, Posgrado en Socioeconomía, Estadística e Informática- \\ Desarrollo Rural, Carretera México-Texcoco Km. 36.5, Montecillo, Texcoco 56230, Estado de México, \\ México. \\ 2 Instituto de Investigaciones Económicas, Universidad Nacional Autónoma de México, Ciudad de la \\ Investigación en Humanidades, Ciudad Universitaria., 04510 Ciudad de México. \\ * Corresponding author: magadan.luis@colpos.mx
}

Gitation: Magadán-Revelo, L. D., Escalona-Maurice, M. J., AguilarIbarra, A., \& Hernández-Juárez M. (2021). The 2030 agenda and its considerations in the framework of artisanal fishing cooperatives in Mexico Agro Productividad. https://doi. org/10.32854/agrop.v14i8.1763

Editor in Chief: Dr. Jorge Cadena Iñiguez

Received: January, 2021. Accepted: July, 2021.

Estimated publication date:

September, 2021

This work is licensed under a Creative Commons Attribution-NonCommercial 4.0 International license.

\section{ABSTRACT}

Objective: To analyze the objectives proposed by the UN, linking them in a theoretical and practical way with the real condition of artisanal fishing cooperatives in Mexico, contrasting the theoretical scope of the 2030 Agenda $v s$. the real praxis of the communities of artisanal fishermen.

Design/Methodology/Approach: Through the application of a Participatory Rapid Appraisal Workshop (PRAW) points of the Agenda 2030 were discussed with three artisanal fishing communities in Mexico. The participants learned in a theoretical way the objectives presented by the UN; selected those that in their opinion are important and punctual parts of their fishing activity; and then analyzed these objectives comparing them with their practical daily reality.

Results: Conclusions and clarifications were obtained from the social subjects in which it was recognized as a general argument that for the Mexican artisanal fishing cooperatives framework the objectives of the 2030 Agenda are possible as long as the action strategy promotes a cooperative culture with community values and social bonds; respect for their environment and way of life; as well as the sustainability of the ocean as their means of work.

Limitations/Implications of the study: the main implication noticed was the enormous importance that exists towards delivering theoretical considerations from international organizations and decision makers, to the social base who operates these proposals. These spaces create discussions that allow the theoretical analysis of practical needs which is mandatory in the social sciences.

Findings/Conclusions: The neoliberal globalized economic system is the main disagreement for the 2030 Agenda. The 2030 Agenda encourages developed countries to support under-developed countries with knowledge, technology and investments to achieve sustainability. However, the Agenda does not recognize local knowledge, use forms and customs in those developing countries, as effective operational alternatives.

Keywords: 2030 Agenda, cooperative fisheries, artisanal fishermen, Theory-Practice. 


\section{INTRODUCTION}

\section{The 2030 agenda, framework of appearance and objectives}

The degradation of the planet, the enormous development gaps among countries, the constant increase in violence, the increase in temperatures derived from climate change; and the huge disparity between rich and poor people have motivated the United Nations (UN) discourse, as an organization of global magnitude, to emphasize their efforts into building and encouraging those life situations involved in the sustainable development of our planet, and therefore of the social groups operating in it.

During 2015, at the United Nations summit, substantial cohort points were worked on for the future development of the world. The main course was the incorporation of the sustainable development concept as a criterion that would unite the actions, proposals and work of citizens, governments and international organizations in a work agenda that generates the necessary transformations to improve the living conditions of all of us, the people inhabiting the planet. As well as to solve and counteract those environmental conditions as pollution and climate change that afflict everyone today.

From September $25^{\text {th }}$ to $27^{\text {th }}, 2015$ at the UN headquarters in New York, USA, the Resolution of the United Nations General Assembly was approved and signed. The document was named "Transforming Our World: the 2030 Agenda for Sustainable Development" (Girón, 2016). Within those pages, 17 objectives and 169 goals were stated (ONU, 2015); which, if accomplished, would face domestic and global challenges of each country (Álvarez, 2016). Thus, changing those conditions of political restrictions, and economic, social and environmental scarcities of the world.

These 17 objectives are organized within a systemic approach, that is, each one of them intervenes and forms an integral part for the implementation of those subsequent. The operation of these objectives and nations' commitment to implement them may be the change that the world needs in order to participate in a dignified life. Through the redistribution of wealth, termination of hunger, sustainable resource management, and ethic revaluation of citizenship (ONU, 2015).

For 15 years after the 2030 Agenda was signed, the core axis guiding the actions of nations should revolve around sustainable growth of under-developed countries within three spheres: economic, social and environmental. Expectations are that the world would take a shift to sustainability for the generations to come.

The objectives stated by the 2030 Agenda are translated into actions, possible and plausible operational goals, which are included in the resolution document signed by the participant nations. These goals are defined as the series of steps to follow to achieve an adequate future prospect. Theoretically, the UN (ONU, 2015) mentions that nations should work under the following strategic terms:

People: through the operation of actions to terminate hunger in the world, ending poverty, and securing the integrated development of human beings in every aspect.

The planet: avoiding soil and natural resources degradation; and promoting their sustainable and rational use. 
Prosperity: promoting a well-being and fulfilling life, striving for economic, social and technological progress, harmonic with nature.

Peace: avoiding and eliminating all trace of social and gender violence, in order to favor more just societies.

Alliances: under the agreement of global solidarity, nations and international organizations will focus their efforts on the needs of the most vulnerable people, proposing sustainable lifestyles.

The objectives and goals of the Agenda entered into force on January 1, 2016 and these should be achieved in the next 15 years. The deadline for this global development plan is 2030 .

The circumscribed objectives in this Agenda ought to be of an "integrated and indivisible nature, of global scope and universal application" (UN 2015, p: 15) and those are categorized as follows: 1) to put an end to poverty in all its forms and throughout the world; 2) to terminate hunger, achieving food security, improving nutrition, and promoting sustainable agriculture; 3 ) to secure healthy lives, promoting well-being at all ages; 4) to ensure inclusive and equitable quality education, facilitating lifelong learning opportunities for everyone; 5) to achieve gender equality empowering all women and girls; 6) to secure availability and sustainable management of water and sanitation for everyone; 7) to guarantee access to affordable, reliable, sustainable and modern energy for all people; 8) to promote sustained, inclusive and sustainable economic growth, through ethic, fulfilling and productive employment for everyone; 9) to build resilient infrastructure, promoting inclusive and sustainable industrialization and fostering innovation; 10) to reduce inequality among and within countries; 11) to make cities and human settlements inclusive, safe, resilient and sustainable; 12) to ensure sustainable production and consumption habits; 13) to take urgent measures to face climate change and its effects; 14) to conserve and sustainably use the oceans, seas and marine resources for sustainable development; 15) to protect, restore and promote sustainable use of inland ecosystems, sustainable forests management, fight against desertification, stopping and reversing land degradation, and halting biodiversity loss; 16) to promote peaceful and inclusive societies for sustainable development, facilitating access to justice for people and building effective and inclusive entities at all levels committed to accountability; and 17) to strengthen the means for goals implementation, revitalizing the Global Partnership for Sustainable Development. All countries, regardless of their development model, need to focus on specific objectives and indicators to achieve their own growth. The international community should support their aspirations. The 2030 Agenda is a useful baseline to guide cooperation and policy coordination (Álvarez, 2016; Girón, 2016).

\section{MATERIALS AND METHODS}

This research focuses on the analysis generated by three communities of artisanal fishermen in Mexico (Puerto San Carlos, BCS; Santa Cruz de Miramar, Nayarit; and Chapala, Jalisco) regarding the goals of the 2030 Agenda. In each community, Participatory 
Rapid Appraisal Workshops (PRAW) were organized for a week with the population dedicated to artisanal fishing. The criteria for participation in the workshops were: 1 ) to be an active party in artisanal fisheries, 2) to belong to any coastal fishery cooperative; and 3) to have interest and time for their participation.

In each locality, groups of 20 social partners met, who analyzed the same document prepared by the UN "Transforming Our World: the 2030 Agenda for Sustainable Development". Subsequently, those goals that, in the opinion of the participants, denoted greater importance in terms of their immediate reality were selected.

After the analysis that was made of each of those selected goals, the participants were encouraged to expose the major problems and disagreements that they perceived between the document and their daily experiences. Afterwards, participants were asked to venture arguments, conclusions, and general opinions either as alternatives to support the achievement of the goals, or as being opposed to them.

Finally, the conclusions obtained were generalized and presented to the participants of the workshops to request the validation of an integrating opinion. The findings from the three communities were integrated by constructing a general document where as far as possible the existing relationship between the theory presented in the UN document and the practical reality of individuals living in social base of artisanal fishing was outlined.

\section{The 2030 Agenda key goals for the development of Mexico's coastal zones and their participation within the fishing cooperatives framework}

Mexico played an active role in the integration of 2030 Agenda, showing concern in terms of improving the quality of life of national inhabitants. For this, Mexico assumed tacitly by signing the resolution, the commitment to achieve the goals stipulated therein through the active cooperation of the Mexican Government, and national lawful organizations, such as production associations; cooperatives; co-state entities; micro and macro incorporations; international organizations such as the International Monetary Fund (IMF) and the World Bank (WB); as well as the United Nations Development Program (UNDP) (Programa de cooperación AMEXCID-PNUD, 2017).

The coastal areas of Mexico and the world are a specific point within the goals set by the 2030 Agenda; particularly represented by the provisions of the aforementioned 14th Goal. The systemic nature of that document invites us to analyze the different objectives that can promote better management of marine and coastal resources; as well as how to increase the quality of life of social partners playing their daily roles near to the coasts.

\section{1) Bringing poverty to end in all its forms in the world:}

This objective aims to transform citizens by encouraging the means of production and ways of life necessary to move from poverty to an economic stratum that allows them the acquisition of the materials necessary for their subsistence. It establishes the access to economic resources and basic services as a human right. Along with the ownership and control of their lands and other assets; their inheritance and natural resources; the use of appropriate technology and adequate financing to carry out the activity to which they are destined (ONU, 2015). All this with the full participation of the political-regulatory 
framework that should provide local, regional, national and international proposals that promote the integrated development of all social partners, focusing as a priority on the sector of the population considered vulnerable.

This goal is opposite to the visible struggle for the commons in the coastal regions, which being a focus of tourism growth cause the artisanal fisherman (the most vulnerable class of fishermen) to be uprooted from the necessary natural resources to carry out their activity. Such a condition is a violation of the guarantees provided in the Mexican Constitution Act, which stipulates that sites which concentrate valuable natural or cultural resources are property of the Nation. Thus, the right of collective use by legally constituted civil organizations is a guarantee that the Mexican State should provide (Martínez and Corgos, 2014).

This is how a huge problem is observed in which artisanal fishermen are stripped of their traditional work areas, confining them to delimited areas of coastal territory to carry out their activity on lands. Also limiting their extraction access to certain nautical areas and target fishing resources, under what is conferred by the somehow infamous fishing permits. In addition to this, the majority of artisanal fishermen have a low technical level in their fishing infrastructure. A fact that does not allow them to improve the yield and revenue of their activity.

The coastal areas of Mexico have a high potential for material reproduction and extraction of resources with high nutritional value (González et al., 2000). If these benefits were launched on the market under an equitable distribution of wealth, valuing the fishing effort, and under proper measures of State regulation, such as warranty prices, the poverty in these areas could be emancipated from society and, in turn, it would contribute to the termination of poverty in other rural and urban areas of Mexico.

The role of the Mexican State in order to achieve the objectives of this first goal must be decisive; through improving the regulations established for the use of natural resources, seeking their sustainability through an active and fair work with society.

In spite of this, the derivation of natural resources from the domain of the coastal states and the handing over of the usufruct to foreign companies, there was evidence in previous years, that the path of change laid on the incorporation of social partners, not as the direct beneficiaries but as the active labor force (Delgado, 2013). The foregoing is verified in the participation of labor employed in cooperative organizations of coastal fishing, where the interaction role of employer-employee began to diminish the intrinsic bond that a commons cooperative should manifest.

That is why the termination of poverty in the fishing communities should extrapolate the relations of labor supremacy that currently occur in the cooperatives, and promote the active, responsible and respectful participation of all partners in the coastal fishery.

\section{2) Terminating hunger, achieving food security, improving nutrition and promoting sustainable agriculture:}

It is framed as a crucial issue closely linked to poverty eradication, since within its precepts the urgent need to secure the means of production is stated. Thus, guaranteeing the necessary means of life, and promoting access to good nutrition with healthy products. 
This objective can be achieved with the support of fish production, since the products obtained by this activity contain a high protein value and are a source of minerals and amino acids (Olivares et al., 2005) necessary for the healthy growth of human beings. However, a marketing plan for seafood must necessarily be established that links the production process with final consumption, and thereby secure the equitable distribution of the wealth generated by fishing (Rubio, 2000). That would give to the producers an opportunity of obtaining a profit for the product offered, also contributing to decrease the purchase prices for the final consumer.

Active participation on the maritime extraction to achieve the referred goals in this objective was considered in the Mexico's National Development Plan 2013-2018, which mentions the need to consolidate a sustainable fishing development, as well as fishermen's participation of fishing resources within their family diet, as an excellent source of high quality nutrients (Gobierno de la República, 2013). Unfortunately, this document does not state how and under what circumstances the current fisheries management shall move towards sustainable fishing.

\section{6) Securing the availability and sustainable management of water and sanitation for everyone}

At this point it is necessary to discuss of the increasing pollution to which our continental and maritime bodies of water are subjected. The use of water resources is of vital importance to sustain life and for the development of every kind of economic activity.

Water for human consumption has become a scarce commodity over some time and future prospects are not encouraging. That is why citizens, private companies and governments must act and face the water problems. To stop contaminating lakes and aquifers, as well as the dumping of biological and chemical waste into rivers and estuarine water bodies, directly connected with seas and oceans.

To guarantee the access to drinking water is not only established as a social benefit; maintaining available sources of fresh water shows respect to the value of biodiversity. In that way this also contributes to the preservation of natural resources, improving the quality of life on the planet.

In many coastal areas of Mexico and their continental sea extent, fish production has diminished due to the problem of pollutants that are dumped daily into the sea. Fish products may become contaminated with toxic elements such as heavy metals (Funes et al., 2007). In addition to the problems of mortality of big marine species or their migration to other parts of the ocean, which make the capture of target species inaccessible for the artisanal fisherman (Perry et al., 2010).

Thus, protecting the planet ecosystems through international cooperation and promoting good practices for conservation become prioritized goals for global welfare (ONU, 2015).

\section{7) Guaranteeing access to affordable, reliable, sustainable and modern energy for all people}

In addition to the objective of sanitation, it is essential to find environmentally friendly forms of energy that promote the proper development of economic activities, without 
jeopardizing the socio-environmental balance of the planet (Naredo, 1999). That is why the seventh goal of the agenda is crucial for all economic sectors of production.

Sustainable practices have been motivated in the fishing activity; as well as the use of efficient technology that mitigates and counteracts the effects of contamination by hydrocarbons and oils in the Mexican seas. The supply of ecological outboard motors has been a measure adopted by the Mexican government, which provides the coastal cooperative member with an option for technological innovation that encourages fuel savings, contributing to avoid atmospheric and ocean pollution (Beltrán and Magadán, 2010). However, equipping the bay fleet with environmentally friendly technology is a daunting task due to the large population dedicated to this activity. But this is the main way that the Mexican government has adopted with the aim to mitigate pollution by fossil fuels discharged into marine ecosystems.

\section{8) Promoting sustained, inclusive and sustainable economic growth, full and productive employment, and decent work for everyone}

This goal pays attention to the growing needs that under-developed countries have to seek sources of employment for their citizens. The governmental revaluation of the work itself as a means of production and social welfare. Salary obtained from work should provide the full maintenance of families, fulfilling their basic needs and giving economic security to people and society.

It is necessary then, to promote public, micro and macroeconomic policies for national and foreign investment, which promote the generation of activities in the three main production sectors. Technological development and the implementation of regulations to legislate and promote good practices and relations at work are a framework that nations should promote.

In the shoreline fishing activity in Mexico, the impact that this objective would have within the fishing production cooperatives would be expressed in the incorporation of social security for their active members. Cooperative organizations are present in the legal framework of Mexican Constitution Act. Social association and unions can promote for their members and for other workers who provide their workforce, improvements in labor relations that allow medical security and funds for retirement at old ages.

The creation of public policies considering perceptions of the coastal fishermen population might be focused and emphasized on specific applications and target objectives at each fishing region within the Mexican State (Buhaya and Ramirez, 2013). This derives from the multifaceted way in which coastal fishing activity is carried out in Mexico. The granting of fishing permits as well as the incorporation of good community practices for social development are some of the activities that should be integrated into the operation management plan of cooperative organizations.

On the other hand, to habilitate a political-social link would guarantee a full development of the activity, fostering the appropriate geographical spaces and means. Linking the cooperative fishing work to the tourist activities that are promoted in the coastal regions could expand the benefits of a sector as vulnerable as the coastal fisherman, incorporate their work capacity to the implementation of tourism activities as well as to the supply of 
food services and maritime transport can promote the economic development of both production sectors.

Likewise, financial institutions must procure the supply of working capital necessary to initialize the fishing activity and this must be repeated until the artisanal fisherman can capitalize their investment and apply it in an emancipated way. The cooperative has access to these credit benefits in a more viable way, however, it must provide the cooperative partner with the necessary education to be able to adequately manage the cash flow and thus change the vision of permanent indebtedness in investments for the sustainable development of activity.

\section{2) Ensuring sustainable consumption and production patterns}

Both internal and external economic exchange, within the increasing neoliberalism framework, have shown restraints and delimitation of areas of commercial influence linked to primary producers.

The necessary economic measures should be implemented to promote an efficient transit between producer and consumer. It is necessary to create public policies that minimize the actions of intermediaries (middlemen); seeking towards a fair price for fishing (Moyano, 2011) would greatly improve both the profit received by coastal fishermen and the acquisition price for the final consumer.

The commercial transit of fish species would lead to a greater domestic demand of fish, which would help improving nutritional values for citizens, and the livelihood of coastal fishermen. This exchange of merchandise should be monitored according to its extent, through guarantee prices that factually add to the income of the shoreline or inland fishery producer.

The active participation of coastal and inland fishing cooperatives in Mexico must be consolidated into the search for points of sale close to final consumers, avoiding intermediaries. On the other hand, the incorporation of added value to seafood is another course of action into which cooperatives can guide their activities. By that means, cooperatives would promote the incorporation of their own labor force within their community; thus, allowing the revaluation of the economic product offered.

\section{3) Taking urgent measures to face climate change and its effects}

This objective could be achieved with the implementation of regulatory measures that reduce the use of fossil fuels and encourage the generation and use of alternative energies that are more environmentally friendly. All the above must be materialized through a strategic planning from the State that allows the incorporation of new technologies, linking environmental education with business and civil action.

Counteracting climate would favor coastal areas thoroughly. Coastline regions are prone to disappearing due to global warming and the melting of the poles. The marine currents have shown an imbalance induced by the increase in ocean temperatures, causing hurricanes and phenomena such as El Niño and La Niña phases of the ENSO to become more violent; and affecting the environment and way of life of the people who inhabit the coasts. The increase of toxic waste discharged into the oceans has resulted in acidification 
of marine ecosystems, killing or causing migration of some marine organisms (Álvarez et al., 2017). Some of those belong to the inventory of target species for coastal or inland fishermen.

\section{4) Conserving and sustainably using the oceans, seas and marine resources for sustainable development}

This objective of the 2030 Agenda safeguards coastal areas and fishing cooperatives in Mexico. It is noteworthy that in the 2030 Agenda this aim has been framed as a particular target on improving the management of oceans, recognizing the paramount importance that these ecosystems have towards the sustainable development of the environment.

A crucial point is to significantly reduce the pollution of the seas, since the biological development of the species that those ecosystems sustain depends on that reduction. Along coastal areas, or in deltas of rivers and streams, the bond shared between sea and land becomes a point of concentration of pollutants as all waste products from the inland will end up in water bodies and these in turn to marine areas. Proper waste management, as well as changing the conditions of use, reuse and recycling can strongly favor the reduction of pollutants discharged into the seas (Álvarez et al., 2017).

Another extremely important aspect is to regulate fishing exploitation with efficient measures and regulations. Fishing cooperatives in Mexico emerged as a means of State control to ensure legitimacy and management of the resources extracted from the Mexican coasts. These regulations should be complemented by incorporating plans for fishing moratorium and catch quotas because, in a historical moment, the fishing cooperatives witnessed that the fishing effort was exponentially increased on certain targeted species. This caused a severe deficit in the populations of those organisms; it was the origin of the subsequent set of productive and economic problems that currently are present in the activity.

That is why efficient regulation through the co-management of resources can offer Mexican artisanal fisheries a forceful way to avoid overexploitation. In the same way, it would serve as a point of cohesion by which fishermen can participate in the care of their resources, thus reducing illegal fishing and wrong practices in the development of their activity, also implementing the use of incidental fishing gear.

The scientific community should be a participant in these efforts by promoting constant studies and monitoring in marine areas; conducting specific research that can contribute to restore the health of the oceans and their sustainable development. Scientific support should be framed within the directions and guidelines of the Transfer of Marine Technology of UNESCO's Intergovernmental Oceanographic Commission (ONU, 2015).

On the other hand, in Mexico the work of scientific research has been disconnected from fishing resources due to budget cuts and the decentralization of institutions dedicated to the study of fishing in Mexico (Villamar et al., 2007), a situation that must be reversed in order to achieve one of the goals present in this objective.

The good management of marine resources is an integral part of the commercial cycle that they have within the Mexican market. Then making real the need to seek out effective 
marketing channels that promote a fair exchange between the fishing activity, and the consumption of the derived products.

The intervention of the federation and of the states, and even of international entities as financial development agencies should support fishing activity. This may be accomplished by directing it towards the acquisition and use of technologies that promote a healthy development. As well as establishing the specific infrastructure necessary in each extractive zone; thereby encouraging the sustainable development of coastal and inland fishing activity in Mexico.

Within the international legal framework, all activities, regulations and adjustments made by nations must be subject to and submitted to the general document issued by the United Nations Convention on the Law of the Sea (ONU, 2015) which serves as a legal framework for development of this activity.

Access to the sea by fishing communities is a customary right directed by traditional uses and customs. That is why to a large extent the activity carried out by shoreline fishermen must be respected and revalued. This access must be regulated and delimited, but never restrictive or detrimental to the livelihood of coastal fishermen. In addition to this, it is necessary to legitimize access to a way of life that meets the basic needs of people. To implement cooperative organizations, that promote community development and social bond within communities, strengthens sustainable development on the three guiding axes in the 2030 Agenda.

\section{GONGLUSION}

The cited objectives of the 2030 Agenda discussed here are those that, in the opinion and experience of the fishermen, and through the eyes of the researcher, circumscribe the actions of cooperative fishing organizations in Mexico. The integrating character that the Agenda promotes is a huge step in the understanding of the world as a systemic subjectobject. As a guideline, the 2030 Agenda offers a path towards improving the world in which we live. However, for these actions to be carried out globally, a series of intrinsic alliances must be presented between developed countries and those under develop, an action that will serve as the engine to achieve the Goals outlined by the Agenda. The globalized neoliberal economic system is the first checkpoint that is presented, since by mentioning the support, subsidies and investments made by the developed countries, it seems to promulgate the overthrow of the national autonomy of the developing countries. Efforts should be focused to provide the appropriate technological knowledge to avoid the use of polluting energies (what would increase the quality of life in the entire planet). But at the same time, the common uses and customs, as well as the local knowledge in each nation, must be recognized to encourage their people participation as an alternative route for effective development.

For the Mexican fishing cooperatives, the course of the objectives is plausible as long as the action strategy promotes a cooperative culture full of community values and social bonds. Along with respect for their environment and way of life, as well as for their work environment and object, the oceans. Cooperative education must be a key element for the sustainable development of coastal areas. 
On the other hand, the creation of an efficient and reliable fishing regulation that starts from the very structure of the State is a crucial point for the proper development of the commercial activities derived from fishing, as well as it is legality and access to fishing resources. To this end, the involvement of cooperative members, freelance and permit fishermen, is mandatory; including these key subjects in those proposals and development models, which have the possibility to be applied in their working areas.

\section{REFERENCES}

Álvarez, A. M. (2016). Retos de América Latina: Agenda para el Desarrollo Sostenible y Negociaciones del siglo XXI. Problemas del Desarrollo. Revista Latinoamericana de Economía, 47(186), 9-30.

Álvarez, M., Arias, A., Lorenzo, M., Serrallé, F. (2017). Educación para la Sustentabilidad: Cambio Global y Acidificación Oceánica. Formación Universitaria, 10(2), 89-102.

Beltrán Espinosa, E., Magadán Revelo, L. D. (2010). Cooperativismo pesquero en la comunidad La Reforma Sinaloa, caso de la pesca artesanal. Universidad Autónoma Chapingo.

Buhaya, D., Ramírez, H. (2013). Análisis de impacto de políticas públicas para el desarrollo local en comunidades costeras y rurales: El caso de la pesca en San Blas, Nayarit. RIDE Revista Iberoamericana para la Investigación y el Desarrollo Educativo, 3(6), 24-43.

Delgado Ramírez, C. E. (2013). La pesca ribereña en el contexto económico capitalista. Apuntes sobre una propuesta de análisis. En G. C. Váldez Gardea, M. S. Galindo Bect, (coords.), Pesquerías globalizadas (pp. 203-221). Hermosillo: El Colegio de Sonora y Universidad Autónoma de Baja California.

Funes Rodríguez, R., Gómez Gutiérrez, J., Palomares García, R. (2007). Estudios ecológicos en Bahía Magdalena (lera ed.). México: Centro de Investigaciones Biológicas del Noroeste, S.C. e Instituto Politécnico Nacional Centro Interdisciplinario de Ciencias Marinas.

Girón, A. (2016). Objetivos del Desarrollo Sostenible y la Agenda 2030: Frente a las políticas públicas y los cambios de gobierno en América Latina. Problemas del Desarrollo. Revista Latinoamericana de Economía, 47(186), 3-8.

González Becerril, A., Espino Barr, E., Gruz Romero, M., Ruiz Luna, A. (2000). Determinación de la unidad de esfuerzo de pesca en una pesquería artesanal ribereña en Manzanillo, Colima, México. Ciencias Marinas, 26(1), 113-124.

Martínez González, P., Corgos López-Prado, A. (2014). La pesca artesanal en Jalisco. Conflictos en torno a la conservación biocultural y la reproducción del capital. El caso de Careyitos. Sociedad y Ambiente, 1(4), 23-38. Doi: 10.31840/sya.v0i4.1522

Moyano, P. (2011). La adaptación del Sistema Nacional de Incentivos Regionales a la Ley para el Desarrollo Sostenible del Medio Rural. Estudios de Economía Aplicada, 29(1), 95-128. Doi: 10.25115/eea.v29i1.3934

Olivares, S., Zacarías, I., Lera, L., Bárbara, L., Durán, R., y Vio del R, F. (2005). Estado nutricional y consumo de alimentos seleccionados en escolares de la región metropolitana: línea base para un proyecto de promoción del consumo de pescado. Revista Chilena de Nutrición, 32(2), 12-22.

ONU. (2015). Transformar nuestro mundo: la Agenda 2030 para el Desarrollo Sostenible. New York.

Programa de cooperación amexcid-pnud. (2017). Buenas prácticas de cooperación internacional para el desarrollo entre el sistema de las Naciones Unidas y el Gobierno Mexicano.

Villamar Calderón, A., Aburto Perdomo, D., Fernández Méndez, J. I., Vázquez, Á., y Rojas Carrillo, P. (2007). Políticas para el fomento de la producción pesquera y acuícola. En J. L. Calva (Ed.), Agenda para el desarrollo. Desarrollo agropecuario, forestal y pesquero (Vol. 9). México: UNAM, Miguel Ángel Porrúa y Cámara de Diputados. 